\section{HERPETOFAUNA OF THE AMRAVATI UNIVERSITY CAMPUS, MAHARASHTRA}

\author{
J.S. Wadatkar \\ P.G. Department of Zoology, Amravati University, Amravati, \\ Maharashtra 444602, India.
}

Amravati University Campus is situated at about $4 \mathrm{~km}$ east of the historic city of Amravati $\left(20^{\circ} 50^{\prime} \mathrm{N} \& 77^{\circ} 47^{\prime} \mathrm{E}\right)$ in the Pohara forest range. The Campus spreads over an area of about 470ac. The University has its own water reservoir covering an area of $1.613 \mathrm{~km}^{2}$ with an irrigation capacity of $0.238579 \mathrm{TMC}$ and number of seasonal streams originate from it. There is very good plantation, grasslands and shrub forests in the campus. Amravati University Campus is covered by hilly forested area of Pohara Malkhed Reserve Forest.

During the study in 1999-2002, reptiles encountered were captured, photographed and identified with the help of field guides (Daniel, 1983; Khaire, 1997). Snakes were identified using scale count as described by Daniel (1983). All the species mentioned were captured alive in the field, by hand or with a stick, identified and then released in the Pohara-Malkhed Reserve Forest or near the reservoir in the University Campus to prevent recapture. Dead specimens that were either killed either by speeding vehicles or by humans were collected. Identification was done at the Department of Zoology, Amravati University, Amravati. Quantitative abundence of few species of snakes is given in Table 1.

During the three year study (January 1999 - December 2002) 19 species of reptiles representing nine different families were recorded. Scientific and common names after Das (2002).

\section{Typhlopidae}

\section{BrahminyBlind Snake - Ramphotyphlops braminus}

Common, recorded mostly in rainy season, generally $8-10 \mathrm{~cm}$ long. Most specimens were observed usually during September every year; however they are seen throughout the year. Thirteen animals were recorded during the study period.

Boidae

\section{Common Sand Boa - Eryx conicus}

Seen only in rainy season from July to September and maximum length recorded was nine inch. Four animals were observed.
Indian Rock Python - Python molurus

Two young ones, 1.5 and $2 \mathrm{ft}$ long were found during the study period. One 6-ft long Python was found in 1996.

\section{Elapidae}

\section{Indian Krait - Bungarus caeruleus}

Recorded less frequently. Two animals were captured during the study period.

\section{Spectacled Cobra - Naja naja}

Indian Cobra is common in the Campus. Totally, 10 individuals were recorded during the study period. Specimens killed by humans or as road kills were recorded. Maximum length recorded was $4 \mathrm{ft}$.

\section{$\underline{\text { Viperidae }}$}

\section{Russell's Viper - Daboia russelii}

The second common snake in the Campus. Frequently observed during the study period. Totally nine individuals were recorded and maximum length was $5 \mathrm{ft}$.

\section{Saw-scaled Viper - Echis carinatus}

Only recorded once in the Campus. Length was $15 \mathrm{in}$.

\section{Colubridae}

\section{Common Wolf Snake - Lycodon aulicus}

Very common, generally found in rainy season and sometimes in winter also. It was recorded more than five times in a year from various buildings or from other areas in the University Campus. A specimen was also collected from third floor of the administrative building of the University. These snakes were found in moult at the University's Orange Garden well. Seven moults were seen during October 2002.

\section{Checkered Keelback Water Snake - Xenochropis piscator}

Common, generally found in rainy season near or in the seasonal streams. They are frequently found at certain spots. Seven animals were found.

\section{Indian Rat Snake - Ptyas mucosa}

Other most common snake in the campus. Maximum length recorded is $8 \mathrm{ft}$ and this specimen was collected from the first floor of a building. A few dead specimens were also found, killed by human beings or as road kills. Total number of individuals recorded during the study period was 11 .

\section{Common Indian Cat Snake - Boiga trigonata}

Not common in the campus. Recorded only once and was $3.5 \mathrm{ft}$ long.

\section{Grass Snake - Macropisthodon plumbicolor}

They are occasionally recorded in grassland or on road side. One specimen was captured and three were found dead in the campus.

Received 3 March 2003; $\quad$ Revised received 1 August 2003; $\quad$ Finally accepted 20 November 2003 


\section{Family: Gekkonidae}

Yellow-green House Gecko - Hemidactylus flaviviridis

Very common in departmental buildings of the University.

Termite-hill Gecko - Hemidactylus triedrus

Recorded once in the campus. It was captured for identification and released.

\section{Family: Agamidae}

Indian Garden Lizard - Calotes versicolor

Very common in the University Campus.

\section{Family: Scincidae}

Spotted Supple Skink - Lygosoma punctata

Recorded only once in the campus.

\section{Keeled Grass Skink - Mabuya carinata}

Common, found under rocks and stones.

Bronze Grass Skink - Mabuya macularia

Generally seen during evening time in the University campus.

\section{Family: Varanidae}

\section{Bengal Monitor - Varanus bengalensis}

Very common, sighted on building walls. Sometimes collected from inside the buildings. Generally young ones are commonly found.

Within nine recorded families of reptiles in Amravati University Campus, there were 12 species of snakes, two species of gekkos, three species of skinks and one species each of Calotes and Varanus. Among the 12 snakes, five belonged to only one family, Colubridae, of which seven were non-poisonous, four poisonous and only one was semi-poisonous. The Saw -scaled Viper (Echis carinatus) which is common in Amravati District was recorded only once in the Campus during the study. Turtles were not recorded during the study period. A suitable reptilian habitat such as gardens, grasslands, streams, nourishing a large number of insects and other species are available in the University Campus to support a rich reptilian diversity.

\section{Acknowledgement}

I am thankful to Dr. G.N. Vankhede, Head, Department of Zoology, Amravati University, for his cooperation and valuable suggestions. I also thank Prof. Avinash Ansare, Director, Physical Education Amravati University, Mr Raghvendra Nande, Member-Wildlife and Environment Conservation Society (WECS), Amravati, for cordial cooperation, participation and valuable support in snake conservation movement.
Table 1. Number of snakes sighted in study area between January 1999 and December 2002.

\begin{tabular}{lc}
\hline English name & Numbers sighted \\
\hline Common Blind Snake & 13 \\
Sand Boa & 04 \\
Indian Python & 02 \\
Common Krait & 02 \\
Indian Cobra & 10 \\
Russell's Viper & 09 \\
Saw-scaled Viper & 01 \\
Wolf Snake & 22 \\
Checkered Keel Back & 07 \\
Rat Snake & 11 \\
Common Cat Snake & 01 \\
Grass Snake & 04 \\
\hline
\end{tabular}

\section{References}

Daniel, J.C. (1983). The Book of Indian Reptiles. Bombay Natural History Society, Bombay.

Das, I. (2002). A Photographic Guide to Snakes and other Reptiles of India. New Holland Publishers, UK, 144pp.

Khaire, N. (1997). Bhartiya Sap (Reptiles of India). Bhartiya Sarpa Vignyan Sanstha, Pune. 